[Review]

\title{
Roles of Glycogen Synthase Kinase-3 (GSK-3) in Cardiac Development and Heart Disease
}

\author{
Fumi TAKAHASHI-YANAGA* \\ Department of Pharmacology, School of Medicine, University of Occupational and Environmental Health, Japan. \\ Yahatanishi-ku, Kitakyushu 807-8555, Japan
}

\begin{abstract}
Glycogen synthase kinase-3 (GSK-3) is a cytoplasmic serine/threonine protein kinase which is known to regulate a variety of cellular processes through a number of signaling pathways important for cell proliferation, stem cell renewal, apoptosis and development. Although GSK-3 exists in a variety of tissues, this kinase plays very important roles in the heart to control its development through the formation of heart and cardiomyocyte proliferation. GSK-3 is also recognized as one of the main molecules that control cardiac hypertrophy and fibrosis. Therefore, GSK-3 could be an attractive target for the development of new drugs to cure cardiac diseases. The present review summarizes the roles of GSK-3 in the signaling pathways and the heart, and discusses the possibility of new drug development targeting this kinase.
\end{abstract}

Keywords : GSK-3, cardiac development, cardiac hypertrophy, cardiac fibrosis.

(Received February 7, 2018, accepted April 6, 2018)

\section{Introduction}

Glycogen synthase kinase-3 (GSK-3) was identified in 1980 as a protein kinase that inactivates glycogen synthase, the rate-limiting enzyme in glycogen synthesis. In the 1990s, GSK-3 was revealed to regulate a number of cellular functions such as cell proliferation, stem cell renewal, apoptosis and development through different signaling pathways $[1,2]$.

The first studies implicating that GSK-3 plays an important role in the heart were published in 2000 and identified GSK-3 as a negative regulator of hypertrophic response in cardiomyocytes $[3,4]$. Since then, a number of studies have been carried out using various models to clarify the roles of GSK-3 in the heart. GSK-3 is now known as a molecule that not only suppresses cardiac hypertrophy but also regulates cardiac development and inhibits cardiac fibrosis.

\section{Glycogen synthase kinase-3 (GSK-3)}

GSK-3 was originally identified as a kinase that can phosphorylate glycogen synthase to inhibit glycogen synthesis. In general, kinases activate their target proteins by phosphorylation. However, in 1980, GSK-3 was found to be an inactivator of glycogen synthase, an enzyme involved in converting glucose to glycogen for storage [1,2].

The GSK-3 family is highly conserved throughout evolution and is encoded by two genes, GSK- $3 \alpha$ and GSK-3 $\beta$, which exist in a variety of tissues $[1,2]$. Although the homology of GSK- $3 \alpha(51 \mathrm{kDa})$ and GSK-3 $\beta$ $(47 \mathrm{kDa})$ is approximately $98 \%$ in the catalytic domain, the overall homology is approximately $85 \%$, because of the differences in their $\mathrm{C}$ - and $\mathrm{N}$ - termini [5]. Due to this similarity in their kinase domains, there is no specific inhibitor for either isoform at present.

GSK-3 is a unique kinase, because its activity is gen-

*Corresponding Author: Fumi TaKahashi-YanaGa, Department of Pharmacology, School of Medicine, University of Occupational and Environmental Health, Japan. Yahatanishi-ku, Kitakyushu 807-8555, Japan, Tel: +81-93-691-7424, Fax: +81-93-601-6264, E-mail: ftakahashi@med.uoeh-u.ac.jp 
erally high in resting cells and phosphorylates substrate proteins to inhibit their functions. This kinase is inhibited in response to cellular signaling mediated by growth factors, cytokines and hormones via the phosphorylation of $\mathrm{Ser}^{21}$ in GSK-3 $\alpha$ and $\operatorname{Ser}^{9}$ in GSK-3 $\beta[1,2]$. Upon inhibition of GSK-3 by various extracellular signaling, downstream effectors are activated to mediate their signaling.

Although the GSK-3 isoforms have similar structures and overlapping functions, the phenotype of global deletion of these isoforms is different. The homozygous knock out (KO) of GSK-3 $\beta$ (GSK-3 $\beta^{-/}$) mice yields an embryonic-lethal phenotype because of hepatic apoptosis or a cardiac patterning defect $[2,6,8]$, while the homozygous knock out of GSK-3 $\alpha$ (GSK-3 $\alpha^{-/}$) mice are viable, fertile, and display a body mass similar to their wild-type littermates [2,9]. Further, only the $\beta$-isoform has an alternatively spliced variant that encodes GSK$3 \beta 2$, which has a 13-residue insert in the kinase domain and is the neuron-specific variant $[10,11]$.

\section{GSK-3 and its role in signaling pathways}

GSK-3 plays central roles in a number of signaling pathways important for development and survival, including the growth factor signaling pathway, the Wnt/ $\beta$ catenin signaling pathway, and the Hedgehog signaling pathway, as described below.

\subsection{GSK-3 in insulin and other growth factor signal- ing pathways}

The control of glycogen synthase is a key step in regulating glycogen metabolism and glucose storage $[1,2]$. GSK-3 directly phosphorylates glycogen synthase, thereby catalytically inactivating glycogen synthase. It had been suggested since 1980 that insulin signaling could inhibit GSK-3 activity, and this supposition was proved in 1995 by Cross et al [12]. They found that insulin activates phosphatidylinositol-3-kinase (PI3K), which phosphorylates Akt, and activated Akt phosphorylates GSK-3 (Ser ${ }^{21}$ in GSK-3 $\alpha$ and Ser $^{9}$ in GSK-3 $\beta$ ), resulting in GSK-3 inactivation [12]. Upon GSK-3 inactivation, downstream effector molecules are activated. This PI3K-Akt-GSK-3-effector cascade is also stimulated by growth factors [e.g., fibroblast growth factor (FGF), epidermal growth factor (EGF) and platelet derived growth factor (PDGF)] and hormones [1, 2] (Fig. 1, left).

\subsection{GSK-3 in the Hedgehog signaling}

The Hedgehog (Hh) signaling pathway has been identified to play an important role not only during development but also in the maintenance of many adult structures, especially in proliferating cell populations [13-15]. Three Hh ligands (Sonic Hedgehog, Indian Hedgehog and Deser Hedgehog) and two receptors [Patched (Ptch) and Smoothened (Smo)] are identified in humans. The activity of the Hh signaling pathway to express target genes is controlled by the Gli family (Gli1, Gli2 and Gli3). In the absence of the $\mathrm{Hh}$ ligands, the Gli family proteins are phosphorylated by protein kinase A (PKA), GSK-3, and casein kinase 1 (CK1), resulting in degradation. The above kinases are inactivated upon the binding of $\mathrm{Hh}$ to its receptors Ptch and Smo, then Gli translocates into the nucleus to activate the expression of the Hh signaling target genes. Thus, GSK-3 plays an important role in controlling Hh signaling activity via the proteolysis of the Gli family (Fig. 1, center).

\subsection{GSK-3 in the Wnt/B-catenin signaling pathway (canonical pathway)}

Cell signaling cascades activated by Wnt proteins (collectively the Wnt signaling pathways) are well conserved throughout evolution. As well as regulating cellular processes, including proliferation, differentiation, motility and survival/apoptosis, the Wnt signaling pathways play key roles in embryonic development and maintenance of homeostasis in mature tissues. Among the described Wnt signaling pathways [the canonical pathway (Wnt/ $\beta$ catenin pathway) and the non-canonical pathways (the planar cell polarity (PCP) pathway, the $\mathrm{Wnt} / \mathrm{Ca}^{2+}$ pathway, and the protein kinase A pathway)], the canonical Wnt signaling pathway is by far the best characterized $[16,17]$.

The activity of the canonical Wnt signaling pathway is dependent on the amount of $\beta$-catenin in the cytoplasm. Without Wnt ligands, cytoplasmic $\beta$-catenin is phosphorylated by the "destruction" complex composed of four different proteins [Axin, adenomatous polyposis coli (APC), CK1 $\alpha$, and GSK-3] and degraded. Upon binding of Wnt to a receptor complex comprised of Frizzleds/low-density lipoprotein receptor-related protein (Fz/LRP), cytoplasmic Dishevelled (Dvl) inhibits GSK-3. Then $\beta$-catenin that escapes 


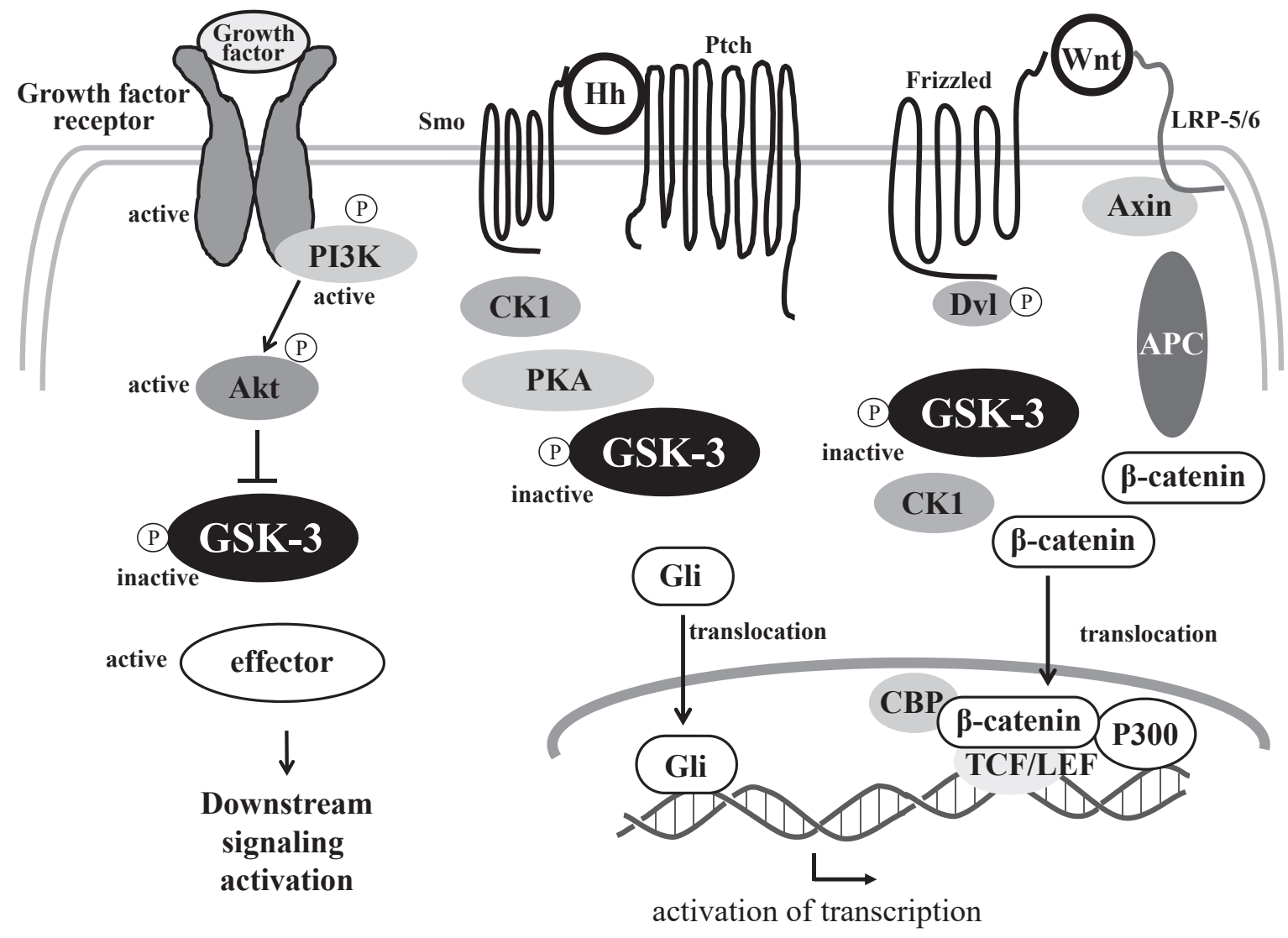

Fig. 1. Roles of GSK-3 in signaling pathways. Without stimulation, GSK-3 activity is high and the activity of the signaling pathway is kept low. Upon binding of a ligand to the receptor, GSK-3 activity is suppressed, thereby activating the signaling pathway. Growth factor signaling (left), Hedgehog signaling pathways (center), and Wnt/ $\beta$-catenin signaling (right) are shown. PI3K: phosphoinositide 3-kinase, GSK-3: glycogen synthase kinase-3, Smo: Smoothened, Hh: Hedgehog, Ptch: Patched, CK1: casein kinase 1, PKA: protein kinase A, Gli: glioma-associated oncogene homolog, Dvl: Dishevelled, LRP-5/6: low-density lipoprotein receptor-related protein- 5/6, APC: adenomatous polyposis coli, CBP: cAMP response element binding protein (CREB)-binding protein, TCF: T-cell factor, LEF: lymphoid enhancer binding factor, P300: E1A binding protein p300.

from degradation translocates into the nucleus and forms a complex with members of the T-cell factor/ lymphoid enhancer binding factor (TCF/LEF) family of transcription factors to activate the expression of Wnt target genes. In this process, GSK-3 plays a key role in controlling the amount of $\beta$-catenin through phosphorylation dependent proteolysis. Thus, the activity of the Wnt/ $\beta$-catenin signaling pathway is mainly regulated through GSK-3 activity (Fig. 1, right).

\section{GSK-3 and cardiac development}

Cardiac development is comprised of a series of morphological events tightly controlled both spatially and temporally. The heart is the first organ to form during embryonic development. This organ arises from two sources of mesoderm, namely the first heart field (FHF) and the second heart field (SHF), which are components of the cardiac crescent and are established during late gastrulation. The cardiac progenitors in the FHF contribute to the left ventricle with small contributions to the atria, whereas the progenitors in SHF contribute to the right ventricle, outflow tract, atria and inflow tract. SHF progenitors (islet 1 expressed cells: Is $11^{+}$cells) demonstrate increased proliferation and delayed differentiation compared with FHF progenitors (Tbx5 expressed cells), which are regulated by FGF, Hedgehog and canonical Wnt signaling pathways [1820]. Moreover, the canonical Wnt signaling pathway has been reported to initiate Isl1 expression (marker for SHF progenitors) and promote the maintenance of mul- 
tipotency of Is $11^{+}$progenitors derived from embryonic stem cells [18]. Therefore, GSK-3 could regulate heart formation via Is11 expression to control proliferation/ differentiation and the maintenance of multipotency in SHF progenitors (Fig. 2).

In cardiac development, especially in cardiomyocyte proliferation, the roles of GSK-3 $\alpha$ and $\beta$ do not overlap. Based on studies using embryonic stem (ES) cells in which one of the isoforms was deleted, GSK$3 \beta$ appears to promote cardiomyocyte differentiation, whereas GSK-3 $\alpha$ plays a much more minor role [7]. It has been shown in an in vivo study that GSK-3 $\alpha$ is not able to compensate for the loss of GSK-3 $\beta$ during cardiac development. GSK-3 $\alpha$ KO mice develop a normal heart, and any cardiac abnormalities do not appear until 8 weeks of age [7,21]. The hearts of embryos in which GSK-3 $\beta$ has been deleted reveal normal valve development, endocardial cushion morphology, and neural crest function, suggesting that GSK-3 $\alpha$ could compensate for the loss of GSK-3 $\beta$ as regards these critical functions. However, there is little or no apparent cavity in the left and right ventricles in GSK-3 $\beta$ $\mathrm{KO}$ mice, because these are packed with cardiomyocytes. This finding indicates that cardiomyocytes in this phenotype fall to hyperproliferation $[2,7]$.

The proliferation of cardiomyocytes during embryonic and fetal development is powerfully driven by GATA binding protein-4 (GATA4) and T-box genes. GATA4 is an essential cardiac transcription factor for cardiac lineage commitment during development, and it is known that this protein is one of the GSK-3 target proteins [22]. As in many other target proteins, phosphorylation of GATA4 by GSK-3 triggers degradation of this transcription factor. Indeed, Kerkela et al reported that the expression level of nuclear GATA4 in embryonic cardiomyocytes was increased in GSK-3 $\beta$ knock out mice [7]. In this report, they also found that, as well as GATA4, cyclin D1 and c-Myc expressions were also increased in GSK-3 $\beta$ KO mice. Cyclin D1 and c-Myc play an important role in the activation of cell cycle progression, which is highly activated in the embryonic and fetal heart. Although both cyclin D1 and c-Myc are known as GSK-3 direct targets, it is also known that expression of both mRNAs are regulated by the canonical Wnt signaling pathway. Therefore, cyclin D1 and c-Myc expression levels are regulated by
GSK-3 on both protein and mRNA levels [23]. Thus GSK-3, especially GSK-3 $\beta$, plays a very important role in cardiomyocyte proliferation via upregulation of GATA4, cyclinD1 and c-Myc expressions (Fig. 2).

\section{GSK-3 and cardiac hypertrophy}

The adult myocardium undergoes hypertrophic growth in response to a variety of diseases, including myocardiac infarction, valvular disease, hypertension, endocrine disorders and inherited mutations in components of the cardiac sarcomere. Although hypertrophy may initially compensate for heart function, prolonged and excessive hypertrophy induces pathological remodeling characterized by abnormal cardiomyocyte size, ventricular dilatation, and/or interstitial fibrosis, and frequently leads to dilated cardiomyopathy and sudden death $[24,25]$.

Several signal transducers, such as mitogen-activated protein kinases, $\mathrm{Ca}^{2+} /$ calmodulin-dependent kinases, and calcineurin $\left(\mathrm{Ca}^{2+} /\right.$ calmodulin-dependent phosphatase) have been implicated in cardiac hypertrophy as positive regulators. On the other hand, a number of endogenous molecules are shown to negatively regulate cardiac hypertrophy [26]. Among many signaling molecules in cardiomyocytes, GSK-3 is a crucial negative regulator of cardiomyocyte hypertrophy [3, 27, 28]. GSK-3 phosphorylates several transcription factors related to cardiomyocyte hypertrophy, such as $\beta$-catenin and nuclear factor of activated T-cell cytoplasmic 3 (NFATc3), to inhibit their functions [26]. Thus GSK-3 inhibits cardiac hypertrophy via the suppression of protein synthesis through $\beta$-catenin and NFATc3 in cardiomyocytes (Fig. 2).

Transgenic constitutive activation of GSK-3 $\alpha$ and/or GSK-3 $\beta$ inhibits cardiac hypertrophy induced by pressure overload or $\beta$-adrenergic receptor stimulation [28, 29]. The activity of GSK-3 is negatively regulated by Akt, which phosphorylates (inactivates) GSK-3 in response to several extracellular signals [26], as shown in Fig. 1. Chronic activation of Akt, which inhibits GSK-3, has been shown to accelerate age-induced cardiac hypertrophy with interstitial fibrosis and contractile dysfunction of the myocardium [30]. These findings strongly indicate that GSK-3 is a crucial regulator of cardiac hypertrophy $[3,27]$, but the exact role of GSK- $3 \alpha$ and GSK-3 $\beta$ in the regulation of cardiac function and stress 
embryo or neonatal heart

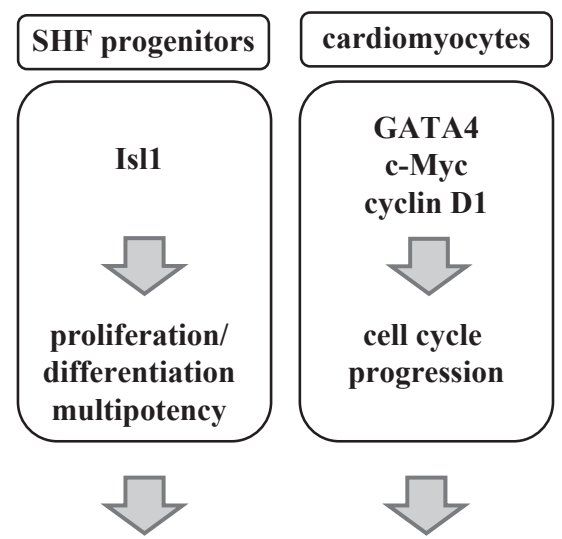

heart formation hyperproliferation

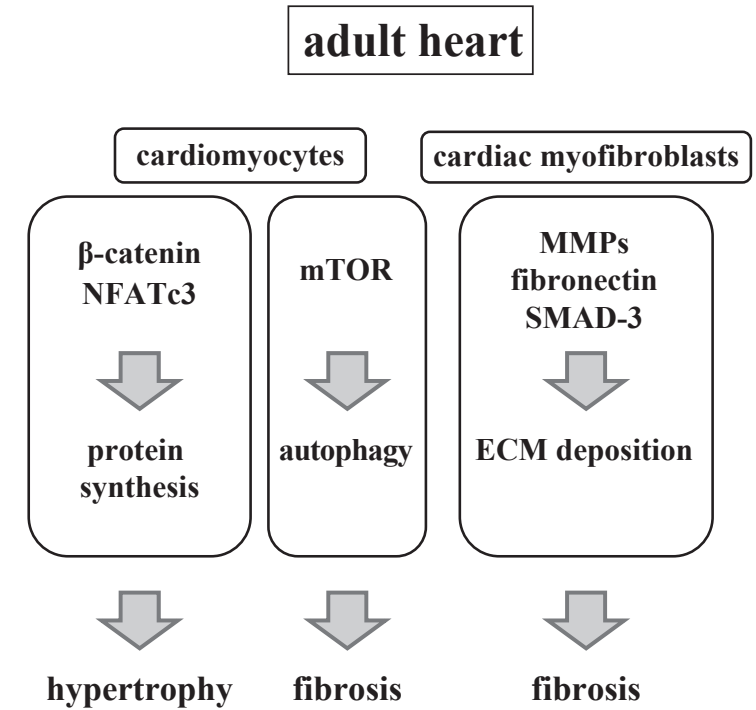

hypertrophy fibrosis fibrosis

Fig. 2. Summary of GSK-3 related actions in the heart. Typical GSK-3 regulated proteins and their functions in embryo/neonatal and adult heart are shown with the observed results. GSK-3: glycogen synthase kinase-3, SHF: second heart field, Is11:islet 1, NFATc3: nuclear factor of activated T-cell cytoplasmic 3, mTOR: mammalian target of rapamycin, MMPs: matrix metalloproteases, ECM: extracellular matrix.

responses in vivo remains unclear. A variety of genetically modified model mice (e.g., global GSK- $3 \alpha$ or $\beta$ knock out, cardiac specific GSK-3 $\alpha$ or $\beta$ overexpression, cardiac specific GSK- $3 \alpha$ or $\beta$ knock out and cardiac specific conditional GSK-3 $\alpha$ or $\beta$ knock out) have been generated and earnest studies have been performed to determine the roles of GSK-3 and each isoform in the heart $[21,28,29,31-36]$, but the results of these studies were not necessarily consistent with each other, as summarized in a recent review article by Lal et al [31]. Although it is quite difficult to clarify the reasons by which the discrepancy of results was observed, one possible reason could be that this discrepancy is due to differences in the experimental models. As recent studies were often performed using cardiomyocyte-specific knock-out or knock-in mice, the expression levels of GSK-3 isoforms and the proteins regulated by GSK-3 in the heart must be different in each model.

\section{GSK-3 and cardiac fibrosis}

In general, heart disease is associated with myocardial fibrosis, which is characterized by the accumulation of activated cardiac fibroblasts and excess deposition of extracellular matrix (ECM). Cardiac fibrosis is classified into two types: reactive fibrosis and replace- ment fibrosis. Reactive fibrosis gradually progresses without the loss of cardiomyocytes, while replacement fibrosis occurs after large numbers of cardiac myocytes defect [37].

Cardiac fibroblasts mainly derive from two different sources, the epicardium and cardiac blood vessels. The epicardium, a layer of connective tissue located between the myocardium and the pericardium, arises from a transient embryonic structure called the proepicardial organ. Some proepicardial cells migrate to the developing heart and contribute to the formation of the epicardial layer. Descendants of proepicardial cells invade the myocardium, where they develop into fibroblasts in the heart and smooth-muscle cells of the coronary arteries. The endothelial cells in blood vessels, the macrophages in blood, and the fibrocytes in bone marrow could be other sources of cardiac fibroblasts, and fibroblasts derived from these sources form fibrosis tissue around blood vessels [38].

The differentiation of cardiac fibroblasts into myofibroblasts is an important process in both types of cardiac fibrosis [20, 38-40]. Myofibroblasts, activated cardiac fibroblasts, are the main source of deposited collagen, fibronectin and other ECM related-proteins, including matrix metalloproteases (MMPs) [37]. It 
has been reported that the expression of some of these proteins, including fibronectin and MMP2, 7 and 9, are regulated by the canonical Wnt signaling pathway, in which GSK-3 is a key regulator [41]. Previous reports have suggested that the gene expressions of extracellular matrix and MMPs are upregulated concomitantly with cardiac fibrosis in failing hearts [42, 43]. It has also been reported that GSK-3 $\beta$ suppresses cardiac fibrosis through a transforming growth factor- $\beta 1$ (TGF$\beta 1)$-contraction of SMAD-3 dependent mechanism. TGF- $\beta 1$ is known to be the key mediator of fibroblast activation and to accelerate the synthesis of ECM in fibrotic diseases. The phosphorylation and nuclear translocation of SMAD2/3 is a rate-limiting step in the TGF- $\beta 1$ signaling pathway and it determines the strength and duration of cellular response. Accumulating evidence suggests that GSK-3 $\beta$ directly interacts with SMAD-3 and negatively regulates its protein stability and enzymatic activity. This action is specific for the GSK-3 $\beta$ isoform, and GSK-3 $\alpha$ does not have a significant effect on SMAD-3 [31, 40]. It has been suggested that the progression of cardiac fibrosis is associated with decreased autophagy $[44,45]$. A recent report showed that inhibition of the Akt/mammalian target of the rapamycin (mTOR) pathway by atorvastatin resulted in augmentation of autophagy in spontaneously hypertensive rats [46]. Autophagy is physiologically important in maintaining the cellular environment by eliminating damaged proteins or organelles. In cardiomyocytes, the inhibition of autophagy may induce apoptosis and trigger interstitial fibrosis [47]. Akt has previously been shown to down-regulate autophagy through the activation of mTOR $[30,36]$. Recently, GSK-3 has also been shown to be involved in the regulation of autophagy; it promotes autophagy through inhibition of mTOR [33]. Correlated with this, suppression of GSK-3 activity/expression has been shown to inhibit autophagy. Zhai et al reported that the inhibition of GSK-3 $\beta$ activity during prolonged myocardial ischemia without reperfusion was associated with suppression of autophagy through activation of the mTOR complex 1 [46]. Lal et al reported that the deletion of GSK-3 $\beta$ from cardiac fibroblasts led to excessive fibrogenesis and scarring in ischemic hearts, impairing cardiac function [31]. Thus, GSK-3 could regulate cardiac fibrosis through regulation of ECM deposition via MMPs and fibronectin expression and autophagy by inhibition of mTOR (Fig. 2).

\section{Conclusion}

As described in this review, GSK-3 plays very important roles in the heart in the regulation of cardiac development, hypertrophy and fibrosis. The modulation of GSK-3 activity can therefore be a new strategy in the treatment of cardiac diseases. Indeed, in the case of cardiac development modulation, the GSK-3 inhibitor BIO has been reported to enhance the growth and survival of cardiac stem cells isolated from patients [48]. In the case of cardiac hypertrophy and fibrosis, it has been reported that genetic and pharmacological inhibition of GSK-3 induced cardiac hypertrophy and fibrosis $[49,50]$. Related to these reports, our research group previously showed that celecoxib and its analogue 2,5-dimethylcelecoxib, both of which could activate GSK-3, prevented cardiac hypertrophy and fibrosis in mice with aortic banding and inherited dilated cardiomyopathy $[51,52]$. As it is well known that cardiac hypertrophy and cardiac interstitial fibrosis are the main pathological features in cardiac remodeling, GSK-3 activators could be used to suppress cardiac remodeling.

GSK-3 is a "very sharp double-edged sword" in cardiac diseases [53], and the roles of each isotype in the heart do not overlap. Therefore, strict control of the activity of each isotype is required in the treatment of cardiac diseases. However, as no isozyme specific GSK-3 activator has been developed yet, the development of an isoform specific activator will be the first step in the development of a new drug targeting this kinase for cardiac diseases.

\section{Conflicts of Interest}

The author has no conflict of interest to declare.

\section{References}

1. Cohen P \& Frame S (2001): The renaissance of GSK3. Nat Rev Mol Cell Biol 2: 769-776

2. Kaidanovich-Beilin O \& Woodgett JR (2011): GSK-3: Functional Insights from cell biology and animal mod- 
els. Front Mol Neurosci 4: 40

3. Haq S, Choukroun G, Kang ZB et al (2000): Glycogen synthase kinase-3 $\beta$ is a negative regulator of cardiomyocyte hypertrophy. J Cell Biol 151: 117-130

4. Morisco C, Zebrowski D, Condorelli G, Tsichlis P, Vatner SF \& Sadoshima J (2000): The Akt-glycogen synthase kinase $3 \beta$ pathway regulates transcription of atrial natriuretic factor induced by $\beta$-adrenergic receptor stimulation in cardiac myocytes. J Biol Chem 275: $14466-14475$

5. Woodgett JR (1990): Molecular cloning and expression of glycogen synthase kinase-3/factor A. EMBO J 9: 2431-2438

6. Hoeflich KP, Luo J, Rubie EA, Tsao MS, Jin O \& Woodgett JR (2000): Requirement for glycogen synthase kinase- $3 \beta$ in cell survival and NF- $\kappa B$ activation. Nature 406: 86-90

7. Kerkela R, Kockeritz L, Macaulay K et al (2008): Deletion of GSK-3 $\beta$ in mice leads to hypertrophic cardiomyopathy secondary to cardiomyoblast hyperproliferation. J Clin Invest 118: 3609-3618

8. MacAulay K, Doble BW, Patel S, Hansotia T, Sinclair EM, Drucker DJ, Nagy A \& Woodgett JR (2007): Glycogen synthase kinase $3 \alpha$-specific regulation of murine hepatic glycogen metabolism. Cell Metab 6: 329-337

9. Doble BW, Patel S, Wood GA, Kockeritz LK \& Woodgett JR (2007): Functional redundancy of GSK-3 $\alpha$ and GSK-3 $\beta$ in Wnt/ $\beta$-catenin signaling shown by using an allelic series of embryonic stem cell lines. Dev Cell 12: 957-971

10. Mukai F, Ishiguro K, Sano Y \& Fujita SC (2002): Alternative splicing isoform of tau protein kinase I/glycogen synthase kinase 3 $\beta$. J Neurochem 81: 1073-1083

11. Saeki K, Machida M, Kinoshita Y, Takasawa R \& Tanuma S (2011): Glycogen synthase kinase-3 $\beta 2$ has lower phosphorylation activity to tau than glycogen synthase kinase-3 $\beta 1$. Biol Pharm Bull 34: 146-149

12. Cross DA, Alessi DR, Cohen P, Andjelkovich M \& Hemmings BA (1995): Inhibition of glycogen synthase kinase- 3 by insulin mediated by protein kinase $\mathrm{B}$. Nature 378: 785-789

13. Ingham PW \& McMahon AP (2001): Hedgehog signaling in animal development: paradigms and principles. Genes Dev 15: 3059-3087

14. Ogden SK, Ascano M Jr, Stegman MA \& Robbins DJ (2004): Regulation of Hedgehog signaling: a complex story. Biochem Pharmacol 67: 805-814

15. Bale AE (2002): Hedgehog signaling and human disease. Annu Rev Genomics Hum Genet 3: 47-65

16. Nelson WJ \& Nusse R (2004): Convergence of Wnt, $\beta$-catenin, and cadherin pathways. Science 303: 14831487

17. Moon RT, Bowerman B, Boutros M \& Perrimon N (2002): The promise and perils of Wnt signaling through $\beta$-catenin. Science 296: 1644-1646

18. Paige SL, Plonowska K, Xu A \& Wu SM (2015): Molecular regulation of cardiomyocyte differentiation. Circ Res 116: 341-353

19. Epstein JA (2010): Franklin H. Epstein Lecture. Cardiac development and implications for heart disease. $\mathrm{N}$ Engl J Med 363: 1638-1647

20. Tian Y, Cohen ED \& Morrisey EE (2010): The importance of Wnt signaling in cardiovascular development. Pediatr Cardiol 31: 342-348

21. Zhou J, Lal H, Chen X et al (2010): GSK-3 $\alpha$ directly regulates $\beta$-adrenergic signaling and the response of the heart to hemodynamic stress in mice. J Clin Invest 120: 2280-2291

22. Yuan X \& Braun T (2017): Multimodal regulation of cardiac myocyte proliferation. Circ Res 121: 293-309

23. Takahashi-Yanaga F (2013): Activator or inhibitor? GSK-3 as a new drug target. Biochem Pharmacol 86: 191-199

24. Levy D, Larson MG, Vasan RS, Kannel WB \& Ho KK (1996): The progression from hypertension to congestive heart failure. JAMA 275: 1557-1562

25. Levy D, Garrison RJ, Savage DD, Kannel WB \& Castelli WP (1990): Prognostic implications of echocardiographically determined left ventricular mass in the Framingham Heart Study. N Engl J Med 322: 1561-1566

26. Hardt SE \& Sadoshima J (2004): Negative regulators of cardiac hypertrophy. Cardiovasc Res 63: 500-509

27. Dorn GW 2nd \& Force T (2005): Protein kinase cascades in the regulation of cardiac hypertrophy. J Clin Invest 115: 527-537

28. Antos CL, McKinsey TA, Frey N, Kutschke W, McAnally J, Shelton JM, Richardson JA, Hill JA \& Olson EN (2002): Activated glycogen synthase-3 $\beta$ suppresses cardiac hypertrophy in vivo. Proc Natl Acad Sci USA 99: 907-912

29. Webb IG, Nishino Y, Clark JE, Murdoch C, Walker SJ, Makowski MR, Botnar RM, Redwood SR, Shah AM 
\& Marber MS (2010): Constitutive glycogen synthase kinase- $3 \alpha / \beta$ activity protects against chronic $\beta$-adrenergic remodelling of the heart. Cardiovasc Res 87: 494-503

30. Hua Y, Zhang Y, Ceylan-Isik AF, Wold LE, Nunn JM \& Ren J (2011): Chronic Akt activation accentuates aginginduced cardiac hypertrophy and myocardial contractile dysfunction: role of autophagy. Basic Res Cardiol 106: 1173-1191

31. Lal H, Ahmad F, Zhou J et al (2014): Cardiac fibroblast glycogen synthase kinase-3 $\beta$ regulates ventricular remodeling and dysfunction in ischemic heart. Circulation 130: 419-430

32. Matsuda T, Zhai P, Maejima Y et al (2008): Distinct roles of GSK- $3 \alpha$ and GSK-3 $\beta$ phosphorylation in the heart under pressure overload. Proc Natl Acad Sci USA 105: 20900-20905

33. Maejima Y, Galeotti J, Molkentin JD, Sadoshima J \& Zhai P (2012): Constitutively active MEK1 rescues cardiac dysfunction caused by overexpressed GSK$3 \alpha$ during aging and hemodynamic pressure overload. Am J Physiol Heart Circ Physiol 303: H979-H988

34. Zhou J, Freeman TA, Ahmad F et al (2013): GSK-3 $\alpha$ is a central regulator of age-related pathologies in mice. J Clin Invest 123: 1821-1832

35. Woulfe KC, Gao E, Lal H et al (2010): Glycogen synthase kinase-3 $\beta$ regulates post-myocardial infarction remodeling and stress-induced cardiomyocyte proliferation in vivo. Circ Res 106: 1635-1645

36. Hirotani S, Zhai P, Tomita H, Galeotti J, Marquez JP, Gao S, Hong C, Yatani A, Avila J \& Sadoshima J (2007): Inhibition of glycogen synthase kinase $3 \beta$ during heart failure is protective. Circ Res 101: 11641174

37. Weber KT \& Brilla CG (1992): Factors associated with reactive and reparative fibrosis of the myocardium. Basic Res Cardiol 87 (Suppl 1): 291-301

38. Souders CA, Bowers SL \& Baudino TA (2009): Cardiac fibroblast: the renaissance cell. Circ Res 105: 1164-1176

39. Fan X, Xie J \& Tian J (2017): Reducing cardiac fibrosis: $\mathrm{Na} / \mathrm{K}$-ATPase signaling complex as a novel target. Cardiovasc Pharm Open Access 6: 204

40. Guo Y, Gupte M, Umbarkar P, Singh AP, Sui JY, Force T \& Lal H (2017): Entanglement of GSK-3 $\beta$, $\beta$-catenin and TGF- $\beta 1$ signaling network to regulate myocardial fibrosis. J Mol Cell Cardiol 110: 109-120
41. Nusse R (2017): The Wnt Homepage. http://web.stanford.edu/group/nusselab/cgi-bin/wnt/ [Access Jan. 4th, 2018]

42. Spinale FG (2002): Matrix metalloproteinases: regulation and dysregulation in the failing heart. Circ Res 90: 520-530

43. MacKenna D, Summerour SR \& Villarreal FJ (2000): Role of mechanical factors in modulating cardiac fibroblast function and extracellular matrix synthesis. Cardiovasc Res 46: 257-263

44. Nakai A, Yamaguchi O, Takeda T et al (2007): The role of autophagy in cardiomyocytes in the basal state and in response to hemodynamic stress. Nat Med 13: 619-624

45. Tsai SC, Yang JS, Peng SF et al (2012): Bufalin increases sensitivity to AKT/mTOR-induced autophagic cell death in SK-HEP-1 human hepatocellular carcinoma cells. Int J Oncol 41: 1431-1442

46. Zhai P, Sciarretta S, Galeotti J, Volpe M \& Sadoshima J (2011): Differential roles of GSK-3 $\beta$ during myocardial ischemia and ischemia/reperfusion. Circ Res 109: 502-511

47. Hua Y, Zhang Y, Ceylan-Isik AF, Wold LE, Nunn JM \& Ren J (2011): Chronic Akt activation accentuates aging-induced cardiac hypertrophy and myocardial contractile dysfunction: role of autophagy. Basic Res Cardiol 106: 1173-1191

48. Tateishi K, Ashihara E, Honsho S et al (2007): Human cardiac stem cells exhibit mesenchymal features and are maintained through Akt/GSK-3 $\beta$ signaling. Biochem Biophys Res Commun 352: 635-641

49. Zhou J, Ahmad F, Parikh S et al (2016): Loss of adult cardiac myocyte GSK-3 leads to mitotic catastrophe resulting in fatal dilated cardiomyopathy. Circ Res 118: $1208-1222$

50. Huisamen B, Hafver TL, Lumkwana D \& Lochner A (2016): The impact of chronic glycogen synthase kinase- 3 inhibition on remodeling of normal and pre-diabetic rat hearts. Cardiovasc Drugs Ther 30: 237-246

51. Fan X, Takahashi-Yanaga F, Morimoto S, Zhan DY, Igawa K, Tomooka K \& Sasaguri T (2011): Celecoxib and 2,5-dimethyl-celecoxib prevent cardiac remodeling inhibiting Akt-mediated signal transduction in an inherited dilated cardiomyopathy mouse model. J Pharmacol Exp Ther 338: 2-11

52. Fujita A, Takahashi-Yanaga F, Morimoto S, Yoshihara 
T, Arioka M, Igawa K, Tomooka K, Hoka S \& Sasaguri $\mathrm{T}$ (2017): 2,5-Dimethylcelecoxib prevents pressureinduced left ventricular remodeling through GSK-3 activation. Hypertens Res 40: 130-139
53. Cheng H, Woodgett J, Maamari M \& Force T (2011): Targeting GSK-3 family members in the heart: A very sharp double-edged sword. J Mol Cell Cardiol 51: $607-613$ 
心臓の発達と病態におけるグリコーゲン合成酵素キナーゼ-3（GSK-3）の役割

高橋 富美

産業医科大学 医学部 薬理学講座

要旨：グリコーゲン合成酵素キナーゼー3(GSK-3) は細胞質に存在するセリン/スレオニンリン酸化酵素であ る。この酵素は細胞増殖, 幹細胞再生, アポトーシス, 発達などに重要な役割を果たすさまざまなシグナル伝達経路 を通じて, 多彩な細胞機能を調節する分子として知られている. GSK-3は生体内に広く分布しているが, 心臟の形成 や心筋細胞の増殖コントロールを通じて, 心蔵の発達に非常に重要な役割を果たしている.さらに, GSK-3は心肥大 や心臟の線維化においても重要な調節因子であることが明らかとなってきた。これらのことから, GSK-3は心疾患 をターゲットとした新薬開発の標的分子として期待されている。この総説では, GSK-3のシグナル伝達経路や心臓 における役割を概説し,この酵素をターゲットとした新薬開発の可能性を論じたい.

キーワード : GSK-3, 心臟の発達, 心肥大, 心蔵線維化. 